\title{
Penerapan Data Mining untuk Mendukung Pemasaran Produk Pinjaman Bank
}

\author{
Sanusi Amir' ${ }^{1}$, Heri Abijono ${ }^{2}$ \\ ${ }^{1}$ Program Studi Teknik Informatika, Sekolah Tinggi Ilmu Komputer Ambon \\ ${ }^{2}$ Program Studi Teknik Informatika, Sekolah Tinggi Teknologi Cahaya Surya Kediri \\ ${ }^{1}$ Sekolah Tinggi Ilmu Komputer Ambon \\ ${ }^{2}$ Sekolah TinggiTeknologiCahaya Surya Kediri \\ E-mail: ${ }^{1}$ ucilinkun9@gmail.com, ${ }^{2}$ ahabijono@gmail.com
}

\begin{abstract}
ABSTRAK
Persaingan di sektor perbankan menuntut setiap bank berlomba untuk membuat jenis-jenis produk kredit yang mampu menarik nasabah agar mau bertransaksi dengan bank. Pemasaran dengan strategi product centric perlu dikombinasikan dengan customer centric untuk menjaga agar Customer Relationship Management tetap terjalin baik dengan nasabah. Identitas nasabah dapat dimanfaatkan untuk merealisasikan konsep strategi pemasaran customer centric. Penelitian ini mendeskripsikan peranan Data Mining terhadap data nasabah yang disertai penerapan teknik Pohon Keputusan dengan algoritma $\mathrm{C} 4.5$ untuk mengidentifikasi field yang paling berpengaruh dalam memprediksi produk-produk pinjaman.

Field data nasabah yang digunakan di penelitian ini meliputi total saldo, tanggal lahir, pekerjaan, dan status. Pemilihan field berdasarkan syarat dan ketentuan yang berlaku untuk masing-masing jenis pinjaman. Hasil penerapan algoritma C4.5 terhadap data nasabah dalam pembentukan pohon keputusan prediksi produk pinjaman terlihat bahwa atribut pekerjaan merupakan atribut yang dominan (nilai Gain tertinggi) di antara atribut-atribut yang lain. Hasil prediksi divalidasi dengan Confusion Matrix dengan nilai akurasi untuk prediksi produk pinjaman sebesar $82 \%$.

Hasil penelitian ini menyimpulkan bahwa database nasabah merupakan sumber data dalam proses prediksi produk pinjaman untuk ditawarkan kepada nasabah, yang dapat dimanfaatkan untuk mendukung pemasaran produk pinjaman bank dengan orientasi customer centric.
\end{abstract}

Kata Kunci-Data, mining, pohon, keputusan, prediksi 


\section{ABSTRACT}

Competition in the banking sector requires every bank to compete to make types of credit products that are able to attract customers to want to transact with banks. Marketing with a product centric strategy needs to be combined with a customer centric to keep Customer Relationship Management in good order with customers. Customer identity can be used to realize the concept of a customer centric marketing strategy. This study describes the role of Data Mining on customer data accompanied by the application of Decision Tree techniques with the C4.5 algorithm to identify the most influential fields in predicting loan products.

The customer data fields used in this study include total balance, date of birth, occupation, and status. Selection of fields based on the terms and conditions that apply to each type of loan. The results of applying the $\mathrm{C} 4.5$ algorithm to customer data in the formation of loan product prediction decision trees show that the work attribute is the dominant attribute (highest Gain value) among the other attributes. Prediction results are validated with Confusion Matrix with an accuracy value for loan product prediction of $82 \%$.

The results of this study concluded that the customer database is a source of data in the prediction process of loan products to be offered to customers, which can be used to support the marketing of bank loan products with a customer centric orientation.

Keyword —Data, mining, trees, decisions, predictions 


\section{PENDAHULUAN}

Ekspansi kredit dan peningkatan dana pihak ketiga serta peningkatan pendapatan merupakan indikator penilaian kinerja sebuah bank. Strategi pemasaran bank disusun oleh pihak manajemen pusat untuk dapat menjadi bank pilihan nasabah dalam melakukan transaksi keuangan. Strategi ekspansi kredit dilakukan dengan cara menerbitkan kebijakan suku bunga single digit untuk kredit produktif, promo berbagai pilihan suku bunga (fix rate) dengan range jangka waktu untuk kredit konsumtif dan biaya administrasi kredit yang bervariasi serta konsistensi waktu proses kredit sesuai Service Level Agreement yang telah ditentukan. Hasil ekspansi kredit akan mendatangkan pendapatan bunga, peningkatan dana pihak ketiga serta penggunaan kartu kredit akan menghasilkan pendapatan dari transaksi keuangan nasabah. Penyaluran kredit wajib perudent agar kualitas kredit berada dalam golongan lancar yang mempengaruhi pencadangan biaya. Penerapan strategi pemasaran bank seperti yang telah dijelaskan di atas dapat dikategorikan sebagai strategi product centric, yaitu pemasaran lebih difokuskan kepada penawaran produk.

Potensi pasar yang sesungguhnya berada dalam lingkungan bank itu sendiri berupa database nasabah, yang dapat dipakai oleh pihak manajemen untuk menganalisis pengetahuan yang tersembunyi untuk mendukung strategi pemasaran bank yang berorientasi customer centric, yaitu pemasaran lebih difokuskan pada kebutuhan nasabah. Pemanfaatan database nasabah dapat menghasilkan informasi sebagai landasan pihak manajemen merumuskan strategi pemasaran bank, sehingga pihak manajemen dapat memasarkan produk baik pinjaman untuk memenuhi kebutuhan nasabah yang telah berstatus menikah dan memiliki anak.

Beberapa penelitian sebelumnya yang telah membahas penerapan teknik data mining dalam perbankan antara lain:

a. Jurnal "Application of Data Mining in the Banking Sector" (Dilmuradjon Zakirov dan Nodar Momtselidze, 2015),

b. M. Preethi dan M. Vijayalakshmi (2017) menulis jurnal "Data Mining In Banking Sector",

c. Penelitian Alisa Bilal Zorić dalam jurnal "Predicting Customer Churn In Banking Industry Using Neural", 
d. Penelitian berjudul "The Application Of Data Mining Techniques In Risk Management In Banking Industry" (Mohammad Khodamoradi dan Rahil Noredin Mosa, 2016),

e. Hany A. Elsalamony (2014) menulis jurnal "Bank Direct Analysis Of Data Mining Techniques", dan

f. Penelitian Olatunji Apampa (2016) dengan judul "Evaluation of Classification and Ensemble Algorithms for Bank Customer Marketing Response Prediction”. Berdasarkan penelitian terdahulu itu maka penelitian saat ini dimaksudkan untuk memprediksi jenis produk pinjaman yang sesuai kepada nasabah Bank menggunakan teknik pohon keputusan dengan algoritma $\mathrm{C} 4.5$.

Berdasarkan latar belakang yang sudah disebutkan di atas, penelitian ini mengangkat dua buah permasalahan yang dapat dirumuskan sebagai berikut:

a. Bagaimana cara memanfaatkan database nasabah dalam mendukung strategi pemasaran bank?

b. Atribut apakah yang paling berpengaruh dalam memprediksi produk-produk pinjaman dan simpanan?

Tujuan yang ingin dicapai melalui penelitian ini adalah:

a. Mendeskripsikan peranan Data Mining serta algoritma C4.5 dalam memanfaatkan database nasabah, dan

b. Mengidentifikasi atribut yang paling berpengaruh untuk memprediksi produkproduk pinjaman.

\section{LANDASAN TEORI}

\subsection{Tinjauan Pustaka}

Jurnal penelitian sebelumnya yang telah membahas penerapan teknik data mining di industri perbankan antara lain dimulai dengan penelitian yang dilakukan oleh Zakirov dan Momtselidze (2015), yang menegaskan bahwa data mining dapat diterapkan untuk keperluan Risk Management, Marketing, Mobile Banking Customer Relationship Management, Fraud Detection, Cross-Selling. Pada penelitian Preethi dan Vijayalakshmi (2017) diungkapkan bahwa data mining memainkan peran penting dalam banyak organisasi. Sangat membantu dalam meneliti data yang dikumpulkan dan mengantarkannya ke dalam pola yang bisa dimengerti. Dalam skenario sekarang, perbankan merupakan sektor yang sedang berkembang dimana besarnya volume data 
elektronik tersimpan. Tugas penting di bidang perbankan adalah menangani transaksional yang besar dan pengambilan keputusan mengenai customer retention, fraud detection, risk and marketing management. Membuat keputusan secara manual tentunya memakan waktu dan rawan kesalahan. Dengan menggunakan beberapa teknik data mining pola dan basis pengetahuan yang tersembunyi dapat diketahui. Peneliti yang lain, yaitu Zorić (2016) meneliti penggunaan data mining dalam industri perbankan dengan metode neural network untuk memprediksi nasabah yang beresiko meninggalkan layanan sebuah bank dan menganalisa apakah nasabah tertentu layak untuk dipertahankan. Dalam melakukan penelitian digunakan perangkat lunak alyuda neurointeligence yang mampu menjalankan proses metode neural network. Proses penelitian diawali dengan definisi masalah dimana masalah bisnis yang spesifik diterjemahkan ke dalam masalah data mining. Data yang telah dikumpulkan ditransformasikan menjadi format yang ditentukan untuk selanjutnya dilakukan proses pembersihan data (menghapus data yang tidak relevan dan tidak akurat). Persiapan data dilakukan beberapa kali dan tidak dalam urutan yang ditentukan. Fase persiapan data bisa memakan waktu hingga $80 \%$ dari semua waktu analisis karena kualitas data merupakan tantangan utama dalam data mining. Selanjutnya teknik permodelan dipilih dan diterapkan. Hasil data mining disajikan kepada pengguna secara visual, karena teknik visualisasi lebih efektif dalam memahami output. Hasil penelitian menunjukkan bahwa nasabah yang menggunakan lebih banyak layanan bank (produk) lebih loyal. Penelitian mengenai risiko kecurangan dan risiko kredit pada bank juga telah diteliti oleh Khodamoradi dan Mosa (2016) dengan mempertimbangkan besarnya volume data yang dihasilkan oleh bank, dibutuhkan model analisa yang sesuai untuk pengambilan keputusan. Hasil penelitian ini menegaskan bahwa bank sebagai lembaga keuangan memerlukan proses manajemen resiko dan data mining adalah alat yang paling penting untuk mengevaluasi, mengidentifikasi dan memprediksi berbagai resiko di depan. Elsalamony (2014) meneliti strategi pemasaran bank tergantung pada pemanfaatan data elektonik nasabah yang sangat besar. Ukuran sumber data ini tidak mungkin bagi seorang analis manusia untuk menghasilkan informasi menarik yang akan membantu pengambilan keputusan. Model data mining sepenuhnya membantu dalam proses ini. Penelitian ini memperkenalkan analisis dan penerapan teknik yang paling penting dalam data mining: multilayer perception neural network, tree augmented naïve bayes known as bayesian networks, nominal regression or logistic regression, and ross quinlan new 
decision tree model. Tujuannya adalah meningkatkan efektifitas strategi pemasaran dengan mengidentifikasi karakteristik utama yang mempengaruhi keberhasilan (produk deposit yang digunakan oleh nasabah) berdasarkan MLPNN, TAN, LR dan C5.0. Hasil eksperimen menunjukkan, dengan akurasi yang lebih tinggi, keberhasilan model ini dalam memprediksi strategi pemasaran terbaik kepada nasabah untuk menggunakan produk deposit. Apampa (2016) melakukan penelitian mengenai pemasaran dengan pemanfaatan database merupakan strategi pemasaran untuk meningkatkan penjualan. Organisasi perusahaan harus menyimpan data pelanggan dan mengembangkan kapasitas untuk dianalisis. Salah satu transaksi yang telah otomatis adalah Customer Relationship Management. Dalam penelitian ini teknik data mining digunakan untuk menentukan pelanggan dan segmen pasar yang akan merespons penawaran oleh perusahaan. Penelitian ini mengandalkan data konsumen digabungkan secara elektronik melalui proses CRM. Penelitian ini mencoba untuk memperbaiki kinerja algoritma klasifikasi yang digunakan di bank berupa prediksi respons pemasaran nasabah dengan menggunakan random forest ensemble. Algoritma klasifikasi yang digunakan untuk memodelkan dataset bank meliputi logistic regression, decision tree, naïve bayes and the random forest ensemble menggunakan aplikasi data mining orange 3.2. hasil metode eksperimental menunjukan bahwa features duration, poutcome, contact, month and housing adalah fitur yang paling penting berkontribusi pada suksesnya strategi pemasaran nasabah bank untuk menggunakan produk deposit. Penelitian ini juga mengungkapkan bahwa durasi panggilan ke nasabah, penggunaan ponsel berkontribusi positif terhadap keberhasilan strategi pemasaran.

\subsection{Dasar Teori}

\section{A. Data Mining}

Menurut Hermawati (2013), data mining adalah proses yang mempekerjakan satu atau lebih teknik pembelajaran komputer (machine learning) untuk menganalisa dan mengekstraksi pengetahuan (knowledge) secara otomatis. Definisi lain diantaranya adalah pembelajaran berbasis induksi (induction-based learning) adalah proses pembentukan definisi-definisi konsep umum yang dilakukan dengan cara mengobservasi contoh-contoh spesifik dari konsep-konsep yang akan dipelajari. knowledge discovery in databases (KDD) adalah penerapan metode saintifik pada data mining. Dalam konteks ini data mining merupakan satu langkah dari KDD. Data 
Mining berisi pencarian trend atau pola yang diinginkan dalam database besar untuk membantu pengambilan keputusan di waktu yang akan datang. Pola-pola ini dikenali oleh perangkat tertentu yang dapat memberikan suatu analisa data yang berguna dan berwawasan yang kemudian dapat dipelajai dengan lebih teliti, yang mungkin saja menggunakan perangkat pendukung keputusan yang lainnya.

Gambar 1 menunjukkan tahapan-tahapan proses dalam penggunaan data mining yang merupakan KDD.

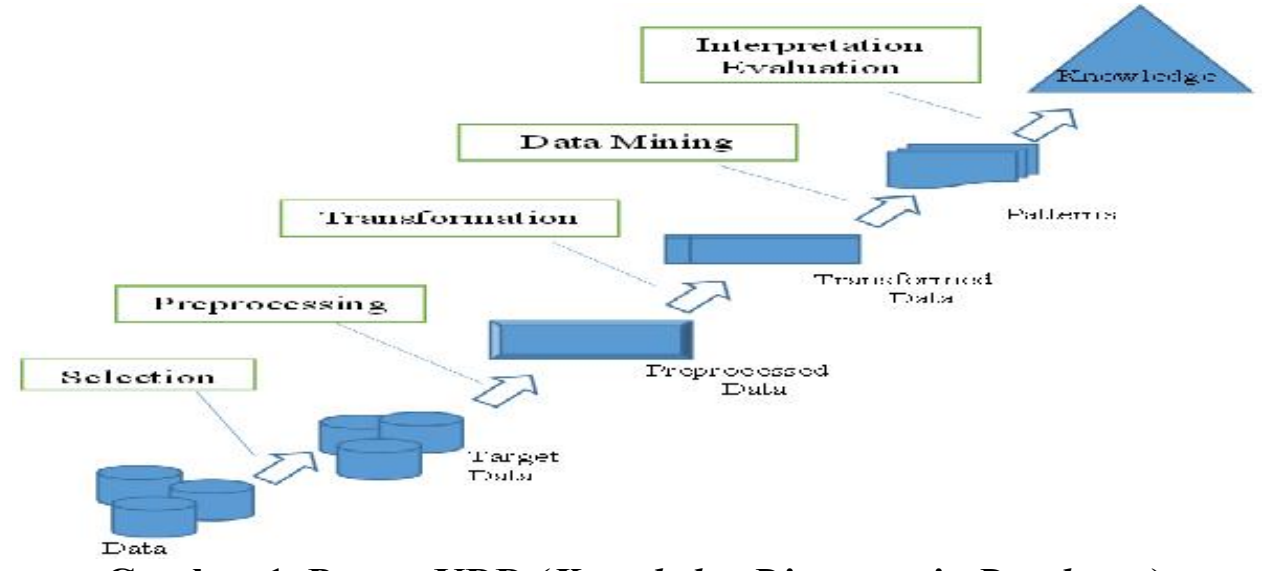

Gambar 1. Proses KDD (Knowledge Discovery in Databases)

Tahapan proses KDD pada Gambar 1 dapat dijelaskan sebagai berikut: 1) Memahami domain aplikasi untuk mengetahui dan menggali pengetahuan awal serta apa sasaran pengguna, 2) Membuat target dataset yang meliputi pemilihan data dan fokus pada subset data, 3) Pembersihan dan transformasi data meliputi eliminasi derau, outliers, missing value serta pemilihan fitur dan reduksi dimensi, 4) Penggunaan algoritma data mining yang terdiri dari asosiasi, sekuensial, klasifikasi, klasterisasi, dll, 5) Interpretasi, yaitu evaluasi dan visualisasi pola untuk melihat apakah ada sesuatu yang baru dan menarik dan dilakukan iterasi jika diperlukan.

Menurut (Fayyad et al., 1996) dalam bukunya Suyanto (2017), data mining adalah analisis terhadap proses penemuan pengetahuan di dalam basis data atau knowledge discovery in databases yang disingkat KDD. Pengetahuan bisa berupa pola data atau relasi antar data yang valid (yang tidak diketahui sebelumnya). Secara umum, kegunaan data mining dapat dibagi menjadi dua: deskriptif dan prediktif. Deskriptif berati data mining digunakan untuk mencari pola-pola yang dapat dipahami manusia yang menjelaskan karakteristik data. Sedangkan prediktif berarti data mining digunakan untuk membentuk sebuah model pengetahuan yang akan digunakan untuk melakukan prediksi. 
Menurut (Larose, 2005) dalam bukunya Kusrini dan Luthfi (2009) data mining merupakan analisis dari peninjauan kumpulan data untuk menemukan hubungan yang tidak diduga dan meringkas data dengan cara yang berbeda dengan sebelumnya, yang dapat dipahami dan bermanfaat bagi pemilik data. Data mining merupakan bidang dari beberapa bidang keilmuan yang menyatukan teknik dari pembelajaran mesin, pengenalan pola, statistik, database, dan visualisasi untuk penanganan permasalahan pengambilan informasi dari database yang besar. Cross-Industry Standard Process for Data Mining (CRISP-DM) yang dikembangkan tahun 1996 oleh analis dari bebarapa industri seperti DaimlerChrysler, SPSS dan NCR. CRISP-DM menyediakan standar proses data mining sebagai strategi pemecahan masalah secara umum dari bisnis atau unit penelitian. Dalam CRISP-DM, sebuah proyek data mining memiliki siklus hidup yang terbagi dalam enam fase seperti yang ditunjukkan melalui Gambar 2 di bawah ini.

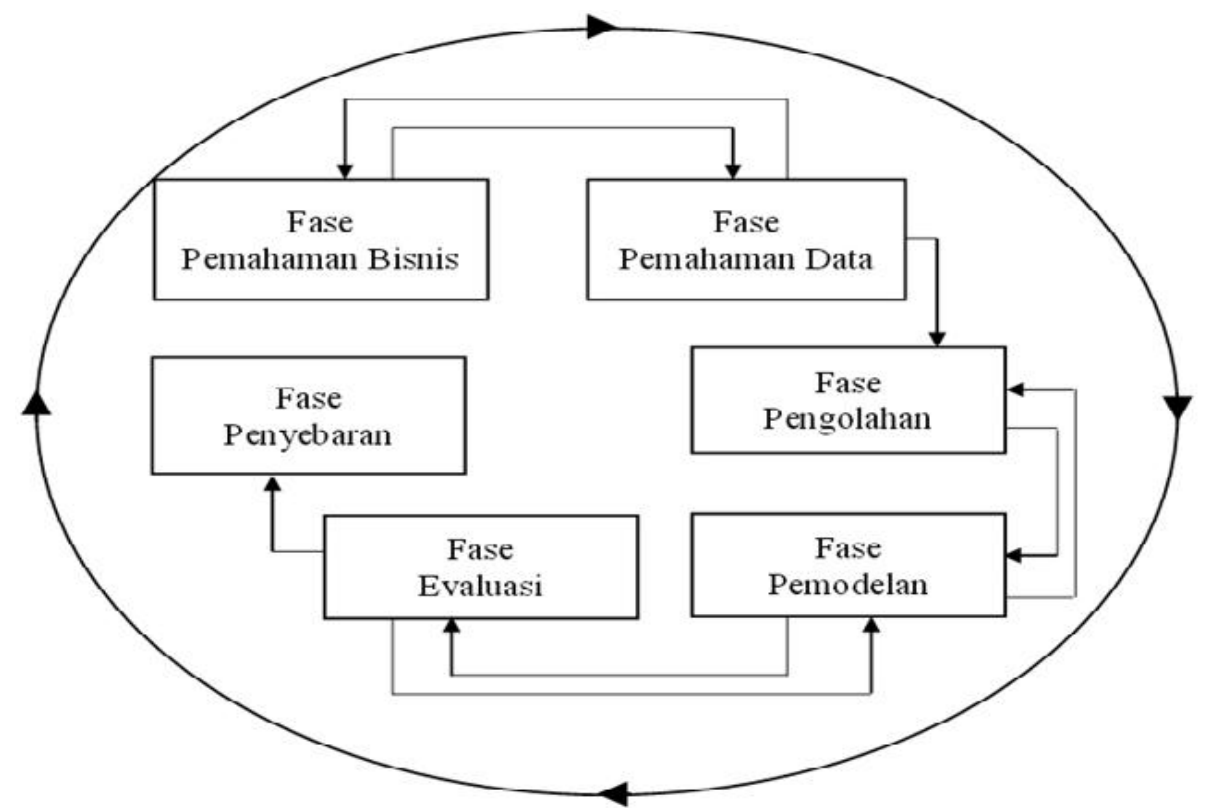

Gambar 2. Proses Data Mining menurut CRISP-DM

Menurut (Chitra dan Subashini, 2013) dalam jurnal Zakirov dan Momtselidze (2015) bahwa terdapat dua kategori dalam data mining yaitu supervisedand unsupervised learning. Kedua konsep tersebut berasal dari machine learning - teknik ini memungkinkan perangkat untuk learning dan memodifikasi fungsi dari hasil kinerja sendiri. Supervised learning disebut juga sebagai directed learning yang berarti proses learning diarahkan oleh atribut yang diketahui sebelumnya dengan tujuan untuk menjelaskan perilaku target sedangkan unsupervised learning dikategorikan sebagai non-directed learning (deteksi pola). Tahapan dalam data mining meliputi data selection, data preparation, data mining, evaluation, representation. 
Dalam jurnal M.Preethi dan M.Vijayalakshmi (2017), data mining atau disebut juga penemuan pengetahuan adalah proses menganalisis data dari berbagai perspektif dan menyimpulkan menjadi infromasi yang bermanfaat. Informasi ini dapat digunakan untuk meningkatkan pendapatan, mengurangi biaya, atau keduanya. Selain itu data mining juga merupakan proses menemukan korelasi atau pola diantara berbagai field dalam basis data yang berukuran besar. Data mining melibatkan proses data cleaning (pembersihan data), data integration, data transformation, data mining, pattern evaluation and data presentation. Setelah seluruh proses dilakukan akan menghasilkan informasi yang dapat diaplikasikan pada berbagai bidang, diantaranya deteksi fraud, analisis pasar, pengendalian produksi, dll.

Menurut (Zorić B.A, 2016) data mining merupakan proses berulang yang tidak berhenti sampai ditemukan solusi. Terdapat empat fase utama dalam data mining yaitu: 1) Fase awal yang mendefinisikan masalah bisnis secara terperinci kemudian diterjemahkan ke dalam masalah data mining, 2) Fase pengumpulan data, pada fase ini data diubah menjadi format yang telah ditentukan untuk dilakukan pembersihan data, yang merupakan proses mendeteksi, mengoreksi serta menghapus data yang tidak sesuai atau tidak relevan. Proses pengumpulan data ini dimungkinkan dilakukan beberapa kali, dan tidak dalam urutan yang ditentukan, 3) Fase pembuatan model dan fase evaluasi, dan 4) Fase penyebaran pengetahuan, merupakan fase penyajian hasil data mining kepada pengguna. Pengetahuan yang ditemukan disajikan secara visual, teknik visualisasi lebih efektif dalam memahami output.

Menurut (Handetal, 2001) dalam jurnal yang ditulis oleh Khodamoradi M. dan Mosa N.R (2016) data mining adalah rangkaian proses analisa data untuk menemukan hubungan yang tidak diketahui sebelumnya hingga memperoleh informasi yang berguna. Selain itu proses data mining digunakan untuk mengidentifikasi pola dalam database yang dapat digunakan dalam pengambilan keputusan. Data mining dapat dimplementasikan pada berbagai sektor diantaranya seperti pemasaran, keuangan, perbankan, manufaktur, manajemen hubungan pelanggan, memprediksi kegagalan dan aplikasi pelatihan pada perusahaan.

Menurut (Ayetiran F.E., 2014) dalam jurnal yang ditulis oleh Elsalamony A.H (2014) data mining atau knowledge discovery dalam database adalah tindakan yang mengekstrak beberapa informasi penting yang terkandung dalam database besar. Target 
data mining adalah menemukan karakteristik yang tidak terduga, fitur tersembunyi atau hubungan tidak jelas lainnya dalam data berdasarkan kombinasi teknik.

Selain itu pengertian data mining dikemukakan oleh Suman, Anuradha dan Veena (2012) dalam jurnal yang ditulis oleh Apampa O. (2016) data mining adalah proses mengekstraksi pola tersembunyi dari data, menganalisis data dan meringkasnya menjadi informasi yang bermanfaat. Dalam data mining terdapat penggunaan statistical analysis, mathematical modelling, artificial intelligence dan machine learning algorithms.

\section{B. Pohon Keputusan}

Haryanto dan Hansun dalam bukunya Slamet, A. (2007), mengatakan Pohon keputusan adalah metode klasifikasi dan prediksi yang sudah terbukti powerfulldan sangat terkenal. Metode ini berfungsi untuk mengubah fakta menjadi pohon keputusan yang merepresentasikan aturan yang dapat mudah dimengerti dengan bahasa alami. Proses dari pohon keputusan ini dimulai dari node akar hingga node daun yang dilakukan secara rekursif dimana setiap percabangan menyatakan kondisi dan setiap ujung pohon akan menyatakan keputusan (Slamet, A., 2007).

Menurut Hermawati (2013), pohon keputusan merupakan representasi sederhana dari teknik klasifikasi untuk sejumlah kelas berhingga, dimana simpul internal maupun simpul akar ditandai dengan nama atribut, rusuk-rusuknya diberi label nilai atribut yang mungkin dan simpul daun ditandai dengan kelas-kelas yang berbeda.

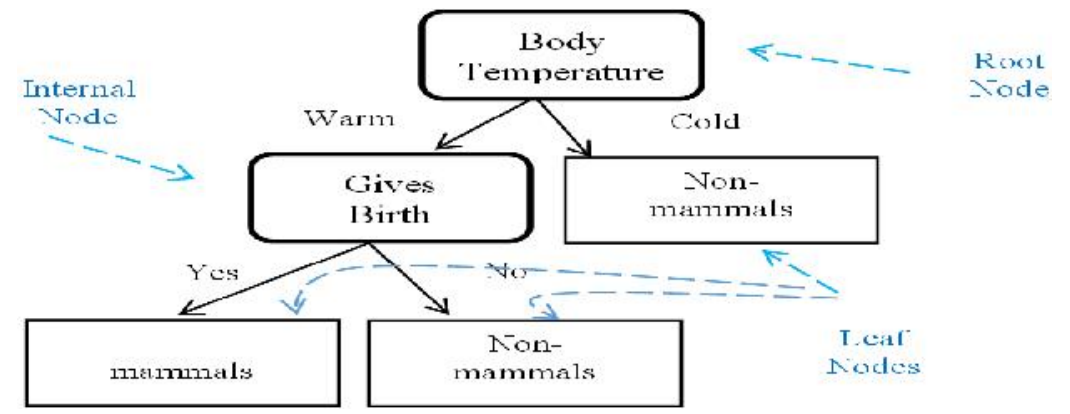

\section{Gambar 3. Contoh Pohon Keputusan untuk Klasifikasi Mamalia}

Objek atau record diklasifikasikan dengan mengikuti suatu jalur (path) yang dimulai dari simpul akar (root), sesuai dengan nilai atribut dalam record tersebut. Misalkan untuk menentukan objek yang bernama 'flamengo' seperti Gambar 3, termasuk kelas apa, dapat ditelusuri pada pohon keputusan Gambar 4, yang dimulai dari simpul akar yang diberi label 'body temperature', dengan melihat nilai atribut 'body temperature' pada data objek dipilih rusuk yang bersesuaian dengan nilai atribut 
tersebut. Demikian seterusnya dilakukan penelusuran sampai diperoleh simpul daun yang menunjukkan kelas dari objek tersebut, yaitu 'non-mammals'. Berarti dapat disimpulkan bahwa Flamingo bukan mamalia. Hermawati (2013)

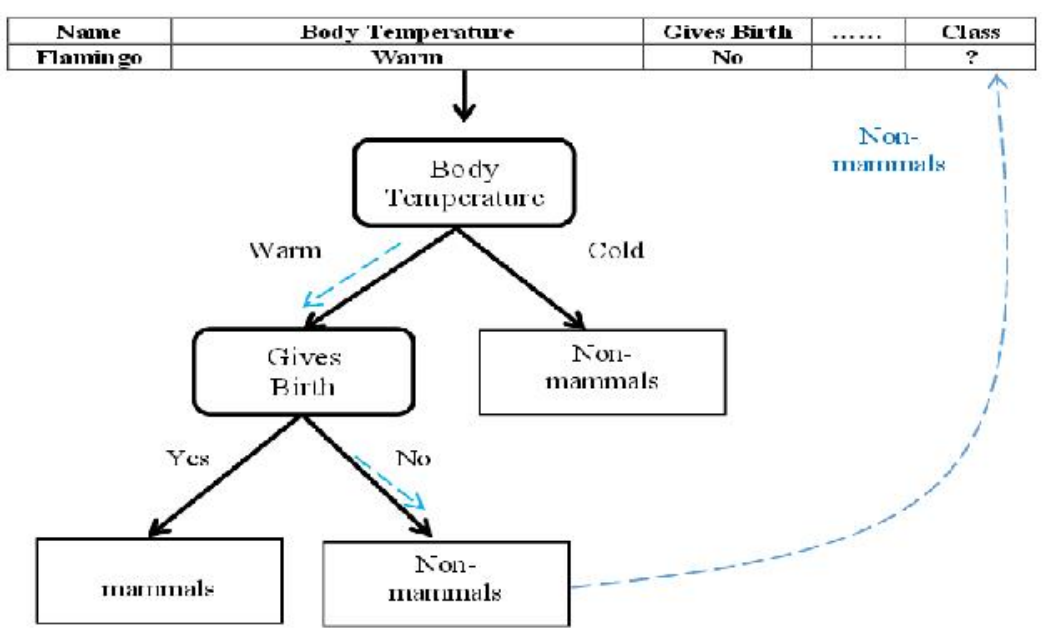

\section{Gambar 4. Contoh Penelusuran Pohon Keputusan untuk Menentukan Kelas dari Objek Flamingo Membangun Pohon Keputusan}

Decision tree (pohon keputusan) merupakan salah satu metoda klasifikasi data mining yang popular digunakan karena mudah diinterprestasikan oleh manusia dengan konsep dasar mengubah data menjadi pohon keputusan dan aturan-aturan keputusan, pengertian ini dikemukakan oleh Berry Michael, J.A., dan Linoff, G.S.(2004) dalam jurnal yang ditulis oleh Hermanto B., Azhari SN., Putra F.P (2017).

\section{Algoritma C4.5}

Menurut Harryanto dan Hansun, Algoritma C4.5 merupakan algoritma yang digunakan untuk melakukan proses klasifikasi data dengan menggunakan teknik pohon keputusan. Algoritma C4.5 merupakan ekstensi dari algoritma ID3 dan menggunakan prinsip decision tree. Algoritma C4.5 dapat mengolah data numerik dan diskret, dapat menangani nilai atribut yang hilang, menghasilkan aturan-aturan yang mudah diinterpretasikan dan performanya merupakan salah satu yang tercepat dibandingkan dengan algoritma lain. Ide dasar dari algoritma ini adalah pembuatan pohon keputusan berdasarkan pemilihan atribut yang memiliki prioritas tertinggi atau dapat disebut memiliki nilai gain tertinggi berdasarkan nilai entropy atribut tersebut sebagai poros atribut klasifikasi. Kemudian secara rekursif cabang-cabang pohon diperluas sehingga seluruh pohon terbentuk. Menurut kamus IGI Global (International Publisher of Progressive Academic), entropy adalah jumlah data yang tidak relevan terhadap informasi dari suatu kumpulan data. Gain adalah informasi yang didapatkan dari 
perubahan entropy pada suatu kumpulan data, baik melalui observasi atau bisa juga disimpulkan dengan cara melakukan partisipasi terhadap suatu set data. Menurut (Jefri, 2013) dalam jurnal Harryanto dan Hansun, Terdapat empat langkah dalam proses pembuatan pohon keputusan pada algoritma C4.5, yaitu 1) Memilih atribut sebagai akar, 2) Membuat cabang untuk masing-masing nilai, 3) Membagi setiap kasus dalam cabang, dan 4) Mengulangi proses dalam setiap cabang sehingga semua kasus dalam cabang memiliki kelas yang sama.

Menurut (Jiandi,2016) dalam jurnal Harryanto dan Hansun, data yang dimiliki harus disusun menjadi sebuah tabel berdasarkan kasus dan jumlah responden sebelum dilakukan perhitungan untuk mencari nilai entropy dan gain. Persamaan 1 merupakan rumus yang digunakan dalam perhitungan entropy yang digunakan untuk menentukan seberapa informatif atribut tersebut.

$$
\text { E } \quad(S)=\sum_{i-1}^{n}-p * \log 2 p
$$

Yang mana 1) $S$ : Himpunan kasus, 2) $n$ : Jumlah partisi $S$, dan 3) pi: Jumlah kasus pada partisi ke-i.

Nilai Gain untuk data terpilih dapat dihitung dengan rumus pada Persamaan 2 di bawah ini.

$$
G \quad(S, A)=E \quad(S)-\sum_{i=1}^{n}\left|\frac{S}{S}\right| * E
$$

Yang mana 1) $S$ : Himpunan kasus, 2) $n$ : Jumlah partisi atribut A, 3) $|S i|$ : Jumlah kasus pada partisi ke-i, dan 4) $|S|$ : Jumlah kasus dalam $S$.

Algoritma C4.5 berfungsi untuk pembentukan pohon keputusan. Perhitungan dimulai dari menghitung banyaknya jumlah atribut dan menentukan atribut mana yang akan digunakan sebagai akar dari pohon keputusan. Selanjutnya akan dilakukan perhitungan entropy dan gain untuk menentukan leaf dari pohon keputusan tersebut. Setelah semua perhitungan selesai dilakukan, pohon keputusan dapat dibentuk berdasarkan nilai gain yang telah dihitung sebelumnya. Atribut dengan nilai gain tertinggi akan terletak pada prioritas yang lebih tinggi dan memiliki kedudukan yang lebih tinggi juga pada pohon keputusan.

\section{Confusion Matrix}

Menurut Cici Olivia dkk (2015), confusion matrix adalah sebuah matriks yang menunjukkan jumlah prediksi yang benar dan tidak benar yang dibuat oleh model klasifikasi dibandingkan dengan hasil aktual (nilai target) dalam data. Matriks n,n 
dengan $\mathrm{n}$ adalah jumlah nilai target (kelas) dapat dibentuk dengan formasi nilai-nilai seperti yang ditulis pada Tabel 1 .

\section{Tabel 1. Model Confusion Matrix}

\begin{tabular}{|l|l|l|l|}
\cline { 3 - 4 } \multicolumn{2}{c|}{} & Nilai Sebenarnya & \multicolumn{1}{l|}{} \\
\cline { 2 - 4 } \multicolumn{2}{c|}{} & True & False \\
\hline \multirow{2}{*}{ Nilai Prediksi } & True & TP (True Postive) & FP (False Positive) \\
\cline { 2 - 4 } & False & FN (False Negative) & TN (True Negative) \\
\hline
\end{tabular}

Berdasarkan model Confusion Matrix pada Tabel 1, nilai akurasi dapat dihitung dengan rumus pada Persamaan 3 di bawah ini:

$$
A \quad=\frac{\mathrm{T}+\mathrm{T}}{\mathrm{T}+\mathrm{T}+\mathrm{F}+\mathrm{F}}
$$

\section{METODE PENELITIAN}

\subsection{Pengumpulan Data}

Data yang dibutuhkan dalam penelitian ini merupakan data nasabah yang diperoleh melalui pemanfaatan tools internal bank (nama bank tidak disebutkan dalam penelitian ini).

\subsection{Metode Analisis Data}

Skenario pengujian ditunjukkan melalui suatu flowchart pada Gambar 5.

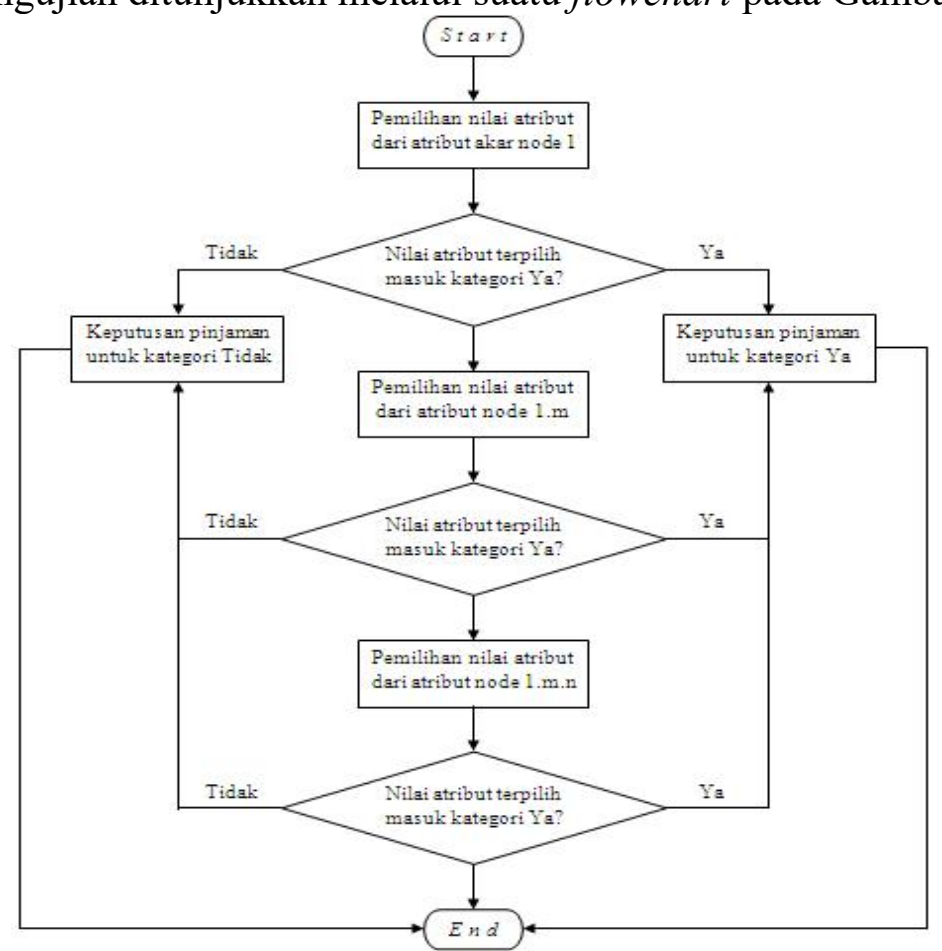

Gambar 5. Skenario Pengujian Data

Proses analisis data yang dilakukan dapat dirincikan sebagai berikut: 
a. Integrasi data, yaitu dengan mengkombinasikan atau mengintegrasikan data sesuai penggunaan tool internal bank untuk menghasilkan data dengan kriteria-kriteria yang dibutuhkan terpisah antara satu data dengan yang lainnya.

b. Seleksi data, yaitu mengambil data sesuai dengan kriteria yang dijadikan dasar pengujian.

c. Analisa data, dilakukan dengan teknik Data Mining model pohon keputusan C 4.5 untuk memprediksi jenis produk pinjaman. Tahapan awal pengujian yaitu ditetapkan jenis-jenis produk pinjaman yang dijadikan acuan prediksi hasil pengujian data. Jenis produk pinjaman meliputi pinjaman perumahan, pinjaman multiguna, pinjaman pegawai, pinjaman pensiunan, dan pinjaman untuk keperluan modal kerja, investasi, maupun kredit usaha rakyat.

d. Menarik kesimpulan, yang didasari pada hasil akhir prediksi produk pinjaman dan simpanan, dimana kombinasi dari beberapa atribut data-data nasabah dapat menghasilkan prediksi produk pinjaman dan simpanan yang dapat ditawarkan.

\section{HASIL DAN PEMBAHASAN}

\subsection{Proses Penyusunan Pohon Keputusan Produk Pinjaman}

Database nasabah bank yang menjadi data dalam penelitian ini terdiri dari 150 data nasabah dengan rincian field berupa CIF, nama nasabah, total saldo, tanggal lahir, agama, pendidikan, pekerjaan, jenis kelamin, status, jumlah anak, jumlah account, nomor telepon, alamat.

Jenis produk pinjaman yang dijadikan kasus untuk pembentukan pohon keputusan adalah pinjaman perumahan, multiguna, pegawai, pensiun yang mana datanya dapat dilihat pada sesuai Tabel 2 di bawah. Produk pinjaman modal kerja, investasi, kredit usaha rakyat tidak dijadikan kasus dalam pembentukan pohon keputusan dengan pertimbangan bahwa tidak terdapat syarat khusus dari produk dimaksud. Hal ini mengindikasikan bahwa setiap nasabah berhak ditawari produk pinjaman modal kerja, investasi dan kredit usaha rakyat.

Tabel 2. Data Keputusan Pinjaman Nasabah

\begin{tabular}{|r|r|l|l|l|}
\hline \multicolumn{1}{|l|}{ No. } & Total Saldo & Tgl. Lahir & Pekerjaan & Keputusan Kredit \\
\hline 1 & 1.002 .524 .799 & $28 / 07 / 1957$ & Pegawai Swasta & Ya \\
\hline 2 & 1.431 .074 .684 & $2 / 02 / 1962$ & Ibu Rumah Tangga & Tidak \\
\hline 3 & 301.161 .397 & $2 / 02 / 1964$ & Wiraswasta & Tidak \\
\hline 4 & 718.318 .886 & $12 / 01 / 1962$ & Pegawai Negeri & Ya \\
\hline 5 & 532.005 .750 & $28 / 09 / 1968$ & Pegawai BUMN/BUMD & Ya \\
\hline
\end{tabular}




\begin{tabular}{|l|l|l|l|l|}
\hline & & & \\
\hline 149 & 137.591 .322 & $29 / 12 / 1972$ & Pegawai BUMN/BUMD & Tidak \\
\hline 150 & 137.635 .131 & $2 / 03 / 1964$ & Pegawai Negeri & Tidak \\
\hline
\end{tabular}

Langkah-langkah pembentukan pohon keputusan dengan menggunakan algoritma C4.5 untuk menyelesaikan permasalahan di Tabel 2 adalah sebagai berikut:

a. Menghitung jumlah kasus untuk keputusan Ya dan untuk keputusan Tidak, dan menghitung nilai entropy untuk semua kasus dan kasus yang dibagi berdasarkan atribut Total Saldo, Tgl Lahir, Pekerjaan. Hasil perhitungan Gain ditunjukkan pada Tabel 3.

Tabel 3. Perhitungan untuk Node 1

\begin{tabular}{|c|c|c|c|c|c|c|c|}
\hline Node & Atribut & Nilai & $\begin{array}{l}\text { Jml } \\
\text { Kasus } \\
(S)\end{array}$ & $\begin{array}{l}\text { Ya } \\
\left(S_{l}\right)\end{array}$ & $\begin{array}{l}\text { Tidak } \\
\left(S_{2}\right)\end{array}$ & Entropy & Gain \\
\hline \multirow[t]{27}{*}{1} & TOTAL & & 150 & 53 & 97 & 0,9370098 & \\
\hline & \multirow{6}{*}{$\begin{array}{l}\text { TOTAL } \\
\text { SALDO }\end{array}$} & $k=250$ Juta & 51 & 0 & 51 & 0 & \\
\hline & & $>250$ Juta $\mathrm{s} . \mathrm{d}<=500$ Juta & 47 & 27 & 20 & 0,9839394 & \\
\hline & & $>500$ Juta $\mathrm{s} . \mathrm{d}<=750$ Juta & 18 & 10 & 8 & 0,9910761 & \\
\hline & & $>750$ Juta $\mathrm{s} . \mathrm{d}<=1 \mathrm{M}$ & 10 & 8 & 2 & 0,7219281 & \\
\hline & & $p 1 \mathrm{M}$ & 24 & 8 & 16 & 0,9182958 & \\
\hline & & & 150 & 53 & 97 & & 0,3147238 \\
\hline & \multirow{3}{*}{$\begin{array}{l}\text { TGL LAHIR } \\
\text { (Usia) }\end{array}$} & Usia $>21$ Tahun & 149 & 53 & 96 & 0,9390599 & \\
\hline & & Usia $<=21$ Tahun & 1 & 0 & 1 & 0 & \\
\hline & & & 150 & 53 & 97 & & 0,0042103 \\
\hline & \multirow{17}{*}{ PEKERJAAN } & Pegawai Negeri & 36 & 20 & 16 & 0,9910761 & \\
\hline & & Pegawai Swasta & 6 & 4 & 2 & 0,9182958 & \\
\hline & & Pegawai BUMN/BUMD & 17 & 14 & 3 & 0,6722948 & \\
\hline & & Wiraswasta & 47 & 0 & 47 & 0 & \\
\hline & & Ibu Rumah Tangga & 10 & 0 & 10 & 0 & \\
\hline & & Dokter & 5 & 5 & 0 & 0 & \\
\hline & & Dosen/Guru Swasta & 1 & 1 & 0 & 0 & \\
\hline & & Dosen/Guru Negeri & 2 & 1 & 1 & 1 & \\
\hline & & Pensiunan & 8 & 6 & 2 & 0,8112781 & \\
\hline & & Pejabat Negara & 1 & 1 & 0 & 0 & \\
\hline & & Pengusaha & 3 & 0 & 3 & 0 & \\
\hline & & Pedagang & 7 & 0 & 7 & 0 & \\
\hline & & TNI/Polri & 3 & 1 & 2 & 0,9182958 & \\
\hline & & Petani/Nelayan & 1 & 0 & 1 & 0 & \\
\hline & & Profesi & 2 & 0 & 2 & 0 & \\
\hline & & Pelajar/Mahasiswa & 1 & 0 & 1 & 0 & \\
\hline & & & 150 & 53 & 97 & & 0,5112589 \\
\hline
\end{tabular}


Setelah dilakukan perhitungan Gain dengan hasil seperti yang tertulis di Tabel 3, kemudian dapat dihitung nilai Entropy untuk semua kasus (di baris TOTAL) dengan memakai rumus pada Persamaan 1, dan diperoleh rincian perhitungan di bawah ini.

$$
\begin{aligned}
E \quad(\text { Total }) & =\left(-\frac{53}{150} * \log _{2}\left(\frac{53}{150}\right)\right)+\left(-\frac{97}{150} * \log _{2}\left(\frac{97}{150}\right)\right) \\
& =0,5303174+0,4066924 \\
& =0,9370098 .
\end{aligned}
$$

Nilai Gain untuk baris TOTAL SALDO dihitung dengan rumus pada Persamaan 2, sehingga dapat diperoleh rincian perhitungan sebagai berikut:

$G \quad(T \quad, T \quad S \quad)$

$$
\begin{aligned}
& =0,9370098-\left(\left(\frac{51}{150} * 0\right)+\left(\frac{47}{150} * 0,9839394\right)+\left(\frac{18}{150}\right.\right. \\
& \left.* 0,9910761)+\left(\frac{10}{150} * 0,7219281\right)+\left(\frac{24}{150} * 0,9182958\right)\right) \\
& =0,3147238 .
\end{aligned}
$$

Hasil perhitungan untuk Node 1 di Tabel 3 menunjukan bahwa atribut dengan Gain tertinggi adalah Pekerjaan, yaitu sebesar 0,5112589, sehingga atribut Pekerjaan menjadi node akar.

Terdapat 16 nilai untuk atribut Pekerjaan, yaitu Pegawai Negeri, Pegawai Swasta, Pegawai BUMN/BUMD, Wiraswasta, Ibu Rumah Tangga, Dokter, Dosen/Guru Swasta, Dosen/Guru Negeri, Pensiunan, Pejabat Negara, Pengusaha, Pedagang, TNI/Polri, Petani/Nelayan, Profesi dan Pelajar/Mahasiswa. Dari 16 nilai atribut tersebut, nilai atribut wiraswasta, Ibu Rumah Tangga, Pengusaha, Pedagang, Petani/Nelayan, Profesi, Pelajar/Mahasiswa telah mengklasifikasikan kasus menjadi satu, yaitu keputusan Tidak. Atribut Dokter, Dosen/Guru Swasta, Pejabat Negara, klasifikasi keputusan menjadi satu, yaitu keputusan Ya. Hasil perhitungan di atas dapat digambarkan pohon keputusan sementara seperti Gambar 6. 


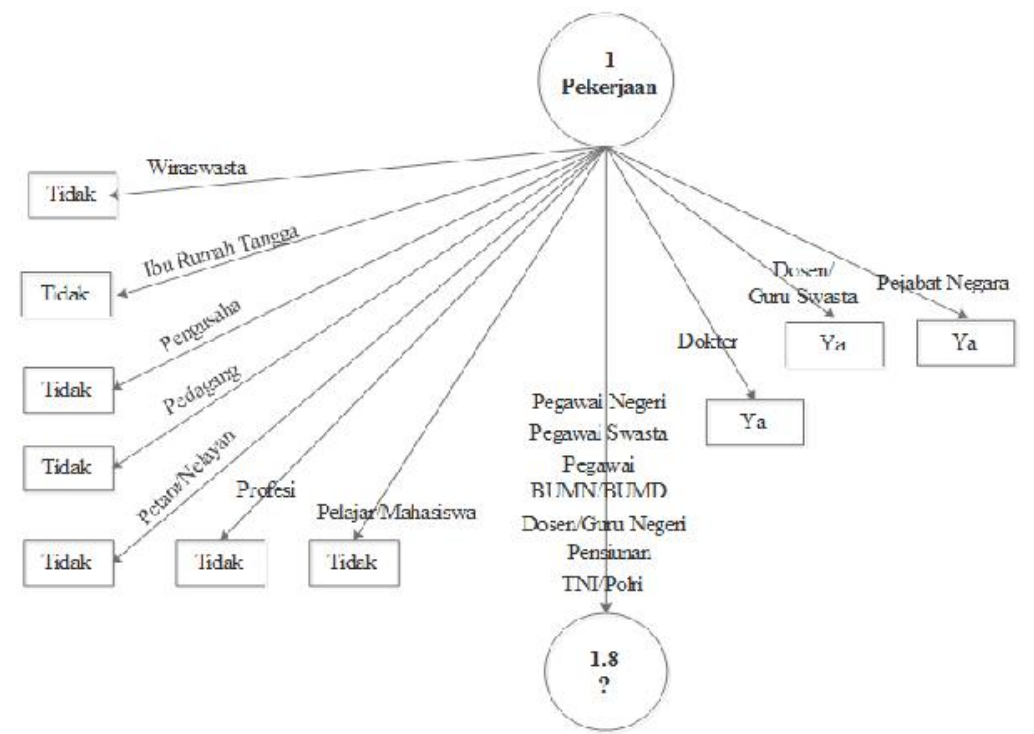

Gambar 6. Pohon Keputusan dari Hasil Perhitungan untuk Node 1

b. Menghitung jumlah kasus untuk keputusan Ya dan Tidak, serta entropy dari semua kasus dan kasus yang dibagi berdasarkan atribut Total Saldo dan Tgl Lahir yang dapat menjadi node akar dari nilai atribut Pegawai Negeri, Pegawai Swasta, Pegawai BUMN/BUMD, Dosen/Guru Negeri, Pensiunan, TNI/Polri. Setelah itu, dilakukan perhitungan gain untuk tiap-tiap atribut. Hasil perhitungan ditunjukkan pada Tabel 4.

Tabel 4. Perhitungan untuk Node 1.8

\begin{tabular}{|c|c|c|c|c|c|c|c|}
\hline Node & Atribut & Nilai & $\begin{array}{l}\text { Jml } \\
\text { Kasus } \\
(S)\end{array}$ & $\begin{array}{l}\text { Ya } \\
\left(S_{1}\right)\end{array}$ & $\begin{array}{l}\text { Tidak } \\
\left(S_{2}\right)\end{array}$ & Entropy & Gain \\
\hline 1.8 & \multicolumn{2}{|c|}{$\begin{array}{l}\text { Pekerjaan - Pegawai Negeri, Pegawai } \\
\text { Swasta, Pegawai BUMN/BUMD, } \\
\text { Dosen/Guru Negeri, Pensiunan, TNI/Polri }\end{array}$} & 72 & 46 & 26 & 0,9436016 & \\
\hline & \multirow{6}{*}{$\begin{array}{l}\text { TOTAL } \\
\text { SALDO }\end{array}$} & $<=250$ Juta & 26 & 0 & 26 & 0 & \\
\hline & & $>250$ Juta s.d $<=500$ Juta & 26 & 26 & 0 & 0 & \\
\hline & & $\geq 500$ Juta s.d $<=750$ Juta & 7 & 7 & 0 & 0 & \\
\hline & & $>750$ Juta $\mathrm{s} . \mathrm{d}<=1 \mathrm{M}$ & 5 & 5 & 0 & 0 & \\
\hline & & $>1 \mathrm{M}$ & 8 & 8 & 0 & 0 & \\
\hline & & & 72 & 46 & 26 & & 0,9436016 \\
\hline & \multirow{3}{*}{$\begin{array}{l}\text { TGL } \\
\text { LAHIR } \\
\text { (Usia) }\end{array}$} & Usia > 21 Tahun & 72 & 46 & 26 & 0,9436016 & \\
\hline & & Usia $<=21$ Tahun & 0 & 0 & 0 & 0 & \\
\hline & & & 72 & 46 & 26 & & 0 \\
\hline
\end{tabular}

Dari hasil perhitungan untuk node 1.8 di Tabel 4, dapat ketahui bahwa atribut dengan Gain tertinggi adalah Total Saldo sebesar 0,9436016, sehingga dapat menjadi node cabang dari nilai atribut Pegawai Negeri, Pegawai Swasta, Pegawai BUMN/BUMD, Dosen/Guru Negeri, Pensiunan, TNI/Polri. Ada lima nilai atribut dari Total Saldo, yaitu 
$<=250$ Juta, $>250$ Juta s.d $<=500$ Juta, $>500$ Juta s.d $<=750$ Juta, $>750$ Juta s.d $<=1 \mathrm{M}$ dan $>1$ M. nilai aribut $<=250$ Juta telah mengklasifikasikan kasus menjadi satu, yaitu keputusan Tidak dan nilai atribut $>250$ Juta $\mathrm{s} . \mathrm{d}<=500$ Juta, $>500$ Juta s.d $<=750$ Juta, $>750$ Juta s.d $<=1 \mathrm{M}$ dan $>1 \mathrm{M}$ sudah mengklasifikasikan kasus menjadi satu dengan keputusan Ya, maka tidak perlu diperlakukan perhitungan lebih lanjut untuk nilai atribut ini. Pohon keputusan yang terbentuk sampai tahap ini ditunjukkan pada Gambar 7.

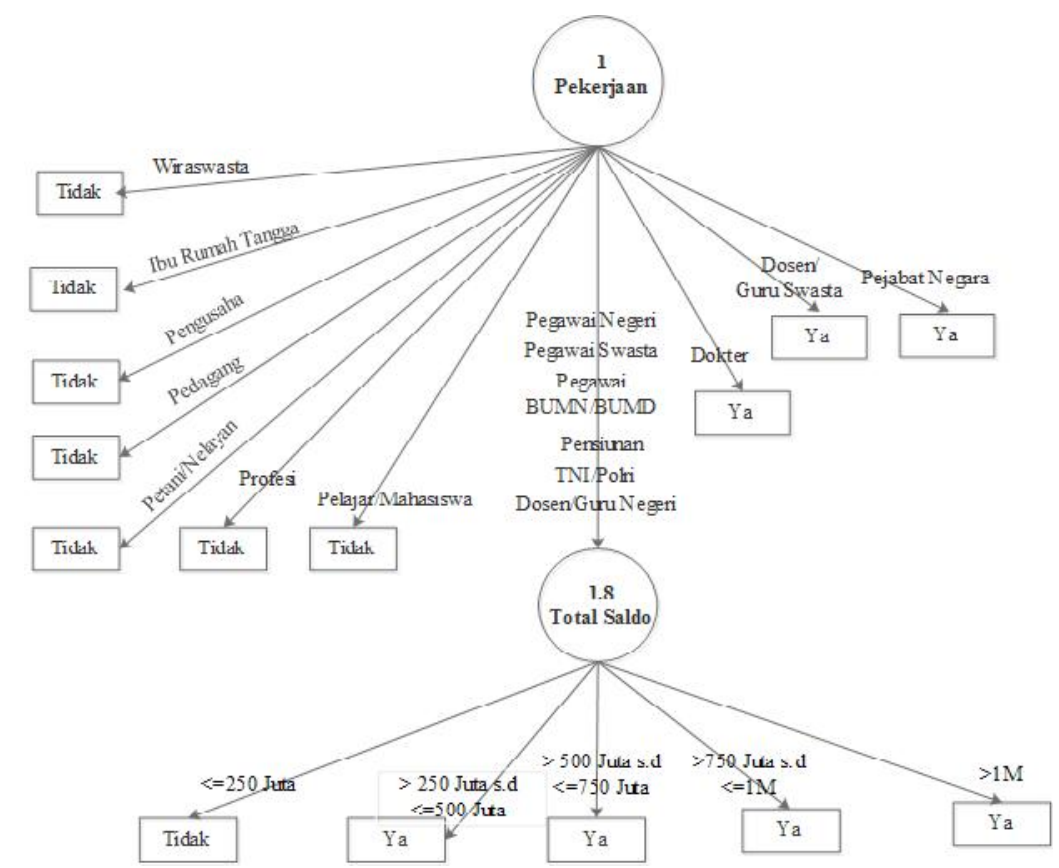

Gambar 7. Pohon Keputusan dari Hasil Perhitungan untuk Node 1.8

Pada Gambar 7 menunjukkan pohon keputusan akhir, sebab semua kasus sudah masuk ke dalam kelas. Dari hasil pohon keputusan akhir kebutuhan nasabah pinjaman ini dapat dibentuk aturan pinjaman sebagai berikut:

1) Jika PEKERJAAN = Wiraswasta atau Ibu rumah tangga atau Pengusaha atau Pedagang atau Petani/Nelayan atau Profesi atau Pelajar/Mahasiswa, Maka Tidak.

2) Jika PEKERJAAN = Dokter atau Dosen/Guru swasta atau Pejabat negara, Maka Ya,

3) Jika PEKERJAAN = Pegawai Negeri atau Pegawai Swasta atau Pegawai BUMN/BUMD atau Pensiunan atau TNI/Polri atau Dosen/Guru Negeri, Dan TOTAL SALDO $=<=250$ Juta, Maka Tidak,

4) Jika PEKERJAAN = Pegawai Negeri atau Pegawai Swasta atau Pegawai BUMN/BUMD atau Pensiunan atau TNI/Polri atau Dosen/Guru Negeri, Dan TOTAL SALDO => 250 Juta $\mathrm{s.d}<=500$ Juta, Maka Ya, 
5) Jika PEKERJAAN = Pegawai Negeri atau Pegawai Swasta atau Pegawai BUMN/BUMD atau Pensiunan atau TNI/Polri atau Dosen/Guru Negeri, Dan TOTAL SALDO $=>500$ Juta $\mathrm{s} . \mathrm{d}<=750$ Juta, Maka Ya,

6) Jika PEKERJAAN = Pegawai Negeri atau Pegawai Swasta atau Pegawai BUMN/BUMD atau Pensiunan atau TNI/Polri atau Dosen/Guru Negeri, Dan TOTAL SALDO $=>750$ Juta $\mathrm{s.d}<=1 \mathrm{M}$, Maka Ya, dan

7) Jika PEKERJAAN = Pegawai Negeri atau Pegawai Swasta atau Pegawai BUMN/BUMD atau Pensiunan atau TNI/Polri atau Dosen/Guru Negeri, Dan TOTAL SALDO $=>750$ Juta s.d $<=1 \mathrm{M}$, Maka Ya.

\subsection{Pengujian Pohon Keputusan Produk Pinjaman}

Pengujian untuk produk pinjaman menggunakan contoh aturan nomor 7 hasil keputusan akhir produk pinjaman, dengan akar dari pohon keputusan produk pinjaman adalah pekerjaan, maka aplikasi pengujian akan menanyakan atribut Pekerjaan.

Gambar 8 di bawah ini menunjukkan interface program ketika melakukan pengujian awal terhadap input data pinjaman.

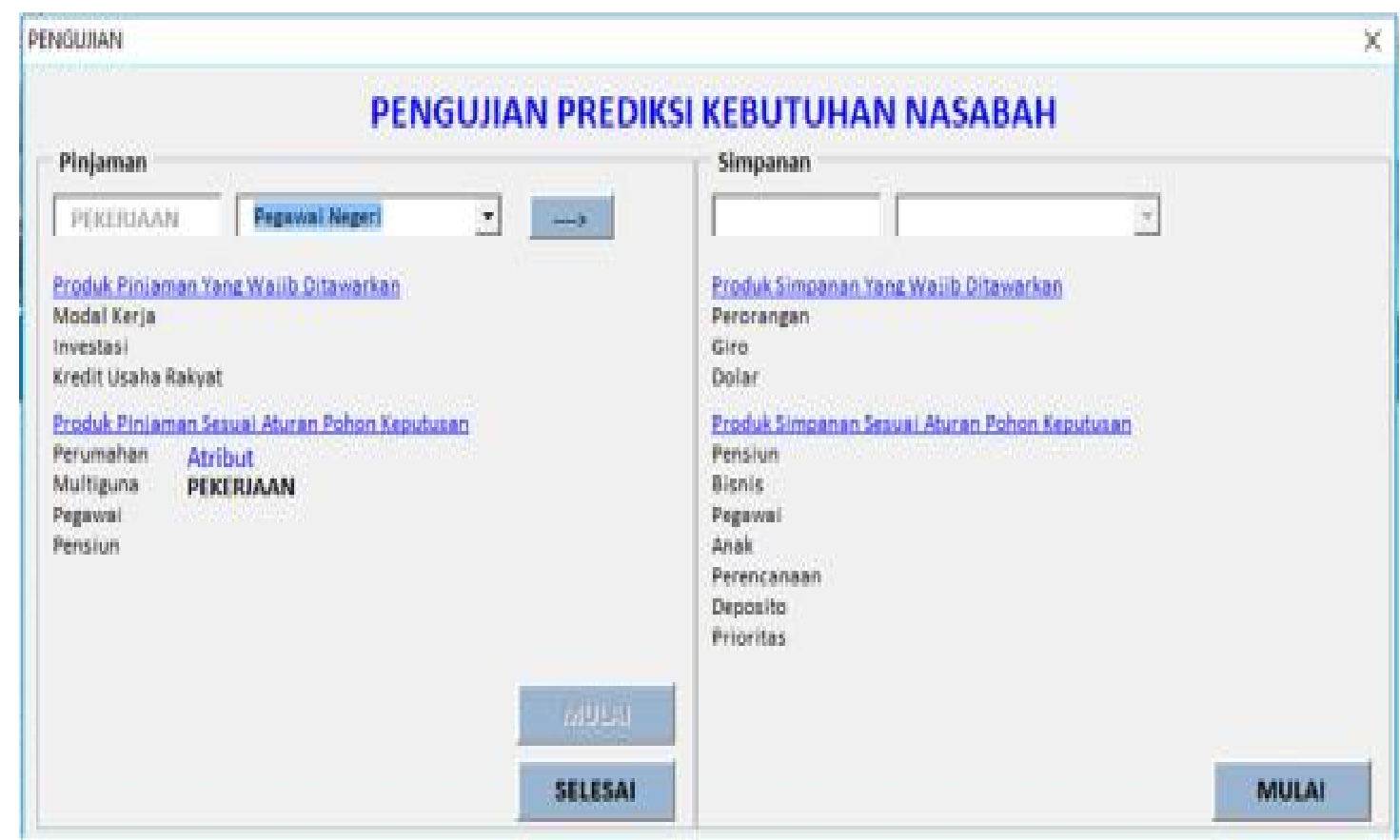

Gambar 8. Pengujian Awal Produk Pinjaman

Gambar 9 di bawah ini menunjukkan interface program ketika melakukan pengujian tahap akhir terhadap input data pinjaman. 


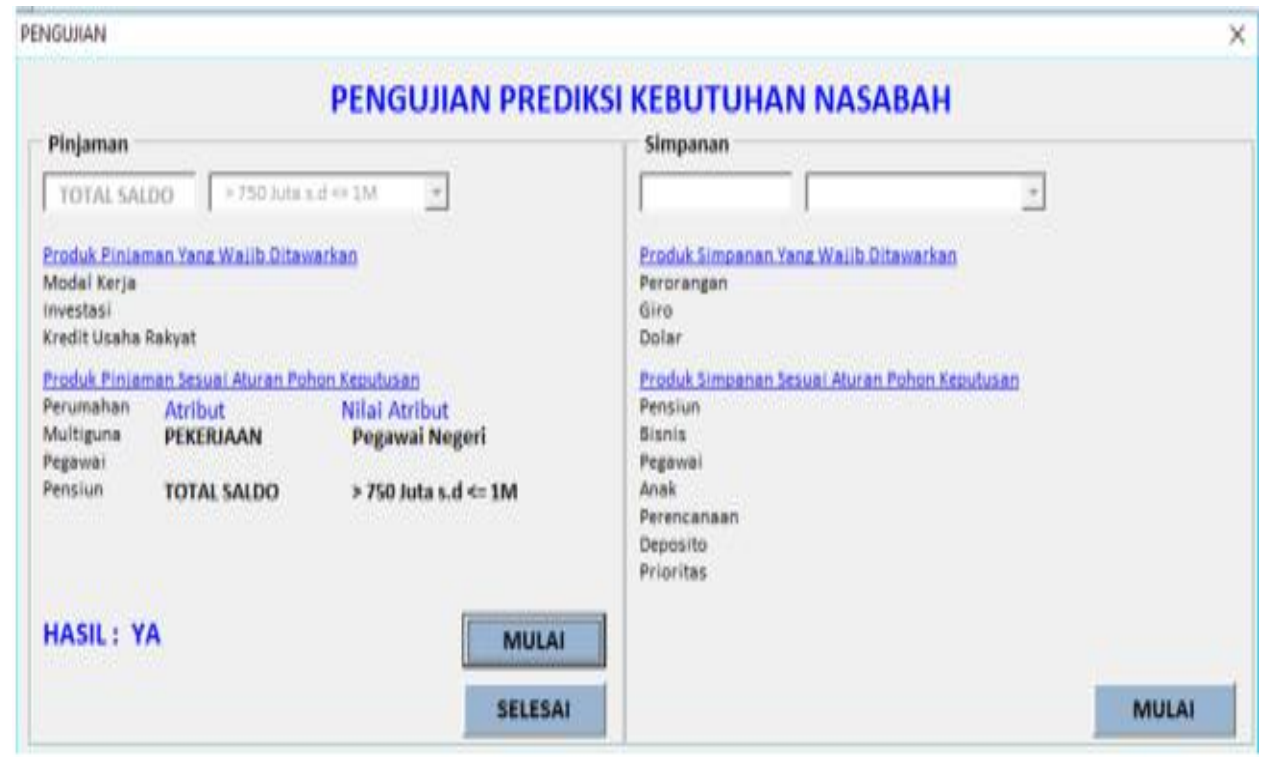

Gambar 9. Pengujian Tahap Akhir Produk Pinjaman

\subsection{Validasi Hasil Prediksi Produk Pinjaman}

Hasil pemasukan 150 data ditunjukkan pada Tabel 5 yang akan menjadi dasar dalam perhitungan nilai akurasi.

Tabel 5. Hasil Pemasukan Data Nilai Sebenarnya dan Nilai Prediksi

\begin{tabular}{|c|c|c|c|c|c|}
\hline \multirow[b]{2}{*}{$\begin{array}{l}\text { Nama } \\
\text { Nasabah }\end{array}$} & \multirow[b]{2}{*}{ Saldo Akhir } & \multirow[b]{2}{*}{ Pekerjaan } & \multirow[b]{2}{*}{ Status } & \multicolumn{2}{|l|}{ Pinjaman } \\
\hline & & & & $\begin{array}{l}\text { Nilai } \\
\text { Sebenarnya }\end{array}$ & $\begin{array}{l}\text { Nilai } \\
\text { Prediksi }\end{array}$ \\
\hline Nasabah 1 & $>1 \mathrm{M}$ & Pegawai Swasta & $\mathrm{M}$ & $\mathrm{Y}$ & Y \\
\hline Nasabah 2 & $>1 \mathrm{M}$ & İbu Rumah Tangga & $\mathrm{M}$ & $\mathrm{T}$ & $\mathrm{T}$ \\
\hline Nasabah 3 & $>250$ Juta $\mathrm{s.d}<=500$ Juta & Wiraswasta & $\mathrm{M}$ & $\mathrm{T}$ & $\mathrm{T}$ \\
\hline Nasabah 4 & $>500$ Juta $\mathrm{s} . \mathrm{d}<=750$ Juta & Pegawai Negeri & $\mathrm{M}$ & $\mathrm{Y}$ & Y \\
\hline Nasabah 5 & $>500$ Juta s.d $<=750$ Juta & Wiraswasta & $\mathrm{M}$ & $\mathrm{T}$ & $\mathrm{T}$ \\
\hline Nasabah 6 & $>500$ Juta $\mathrm{s} . \mathrm{d}<=750$ Juta & Pegawai BUMN/BUMD & $\mathrm{M}$ & $\mathrm{Y}$ & $\mathrm{Y}$ \\
\hline Nasabah 7 & $>750$ Juta $\mathrm{s.d}<=1 \mathrm{M}$ & Pegawai Negeri & $\mathrm{M}$ & $\mathrm{Y}$ & $\mathrm{Y}$ \\
\hline Nasabah 8 & $>1 \mathrm{M}$ & Wiraswasta & $\mathrm{M}$ & $\mathrm{T}$ & T \\
\hline Nasabah 9 & $>250$ Juta s.d $<=500$ Juta & Pegawai BUMN/BUMD & $\mathrm{M}$ & $\mathrm{Y}$ & $\mathrm{Y}$ \\
\hline Nasabah 10 & $>250$ Juta $\mathrm{s} . \mathrm{d}<=500 \mathrm{Juta}$ & Pegawai Negeri & $\mathrm{M}$ & $\mathrm{Y}$ & Y \\
\hline Nasabah 11 & $>1 \mathrm{M}$ & Wiraswasta & $\mathrm{M}$ & $T$ & $\mathrm{~T}$ \\
\hline Nasabah 12 & $>250$ Juta s.d $<=500$ Juta & Pegawai Negeri & M & $\mathrm{Y}$ & $\mathrm{Y}$ \\
\hline Nasabah 13 & $>750$ Juta $\mathrm{s.d}<=1 \mathrm{M}$ & Dokter & M & $\mathrm{Y}$ & Y \\
\hline Nasabah 14 & $>750$ Juta $\mathrm{s} . \mathrm{d}<=1 \mathrm{M}$ & Pejabat Negara & $\mathrm{L}$ & $\mathrm{Y}$ & $\mathrm{Y}$ \\
\hline Nasabah 15 & $>1 \mathrm{M}$ & Wiraswasta & $M$ & $\mathrm{~T}$ & $\mathrm{~T}$ \\
\hline Nasabah 16 & $>1 \mathrm{M}$ & Pegawai Negeri & M & $\mathrm{Y}$ & Y \\
\hline Nasabah 17 & $>250$ Juta s.d $<=500$ Juta & Pegawai Negeri & $\mathrm{M}$ & $\mathrm{Y}$ & Y \\
\hline Nasabah 18 & $>500$ Juta s.d $<=750$ Juta & Dosen / Guru Swasta & $\mathrm{M}$ & $\mathrm{Y}$ & |Y \\
\hline Nasabah 19 & $>250$ Juta $s . d<=500$ Juta & Wiraswasta & M & $\mathrm{T}$ & $\mathrm{T}$ \\
\hline Nasabah 149 & $k=250$ Juta & Pegawai BUMN/BUMD & $\mathrm{L}$ & $\mathrm{T}$ & $\mathrm{T}$ \\
\hline Nasabah 150 & $<=250$ Juta & Pegawai Negeri & $\mathrm{L}$ & $\mathrm{T}$ & $\mathrm{T}$ \\
\hline
\end{tabular}


Perhitungan nilai akurasi dengan rumus pada Persamaan 3 diperoleh rincian perhitungan di bawah ini:

$$
\begin{aligned}
& A \quad p \quad p \quad p \quad=\frac{31+92}{31+92+22+5} \\
& =\frac{123}{150} \\
& =0.82=82 \% .
\end{aligned}
$$

\section{KESIMPULAN}

Berdasarkan permasalahan-permasalahan yang dirumuskan pada penelitian ini, terdapat dua kesimpulan yang dapat dibuat penulis, yaitu:

a. Database nasabah dapat dijadikan sumber data dalam proses prediksi produkproduk pinjaman dan simpanan untuk ditawarkan kepada nasabah existing. Hasil prediksi dapat dimanfaatkan untuk mendukung strategi pemasaran Bank yang berorientasi customer centric.

b. Atribut pekerjaan merupakan atribut yang paling berpengaruh (nilai Gain terbesar) di antara atribut-atribut yang lain.

\section{SARAN}

Saran-saran yang dapat digunakan untuk penelitian di waktu yang akan datang meliputi:

a. Penggunaan data nasabah sebaiknya dalam jumlah yang lebih besar agar lebih maksimal dalam proses pengujian data, dan

b. Perlu dilakukan data cleaning rutin untuk menghindari nilai atribut yang kosong.

\section{DAFTAR PUSTAKA}

[1] Hermawati, A. F., (2013), Data Mining, Andi, Yogyakarta.

[2] Suyanto, (2017), Data Mining untuk Klasifikasi dan Klasterisasi Data, Informatika, Bandung.

[3] Kusrini, Luthfi T.E., (2009), Algoritma Data Mining, Andi, Yogyakarta.

[4] Zakirov D., Momtselidze N., (2015), Application of Data Mining in the Banking Sector, Journal of Technical Science and Technologies, ISSN 2298-0032, Volume 4 Issue 1.

[5] Preethi M., Vijayalakshmi M., (2017), Data Mining In Banking Sector, International Journal of Advanced Networking \& Applications (IJANA) Volume: 08 Issue: 05 Pages: 1-4 (2017) Special Issue. 
[6] Zorić B.A., (2016), Predicting Customer Churn In Banking Industry Using Neural Networks, Interdisciplinary Description of Complex Systems 14 (2), 116124.

[7] Khodamoradi M., Mosa N.R., (2016), The application of data mining techniques in risk management in banking industry, Extensive Journal of Applied Sciences, EJAS Journal-2016-4-5, 163-167, ISSN 2409-9511.

[8] Elsalamony A.H., (2014), Bank Direct Marketing Analysis of Data Mining Techniques, International Journal of Computer Applications (0975-8887), Volume 85-No 7, January 2014.

[9] Apampa O., (2016), Evaluation of Classification and Ensemble Algorithms for Bank Customer Marketing Response Prediction, Journal of International Technology and Information Management Volume 25 | Issue 4 Article 6.

[10] Cici Olivia, Indriwiarti, dan Yulian Sibarani, 2014, Analisis Prediksi Churn Menggunakan Metode Logistic Regression Dan Algoritma Decision Tree, Pustaka Laporan Penelitian, Ilmu Komputasi Universitas Telkom, ISSN :2355-9365, e-Proceeding of Engineering : Vol.2, No.2 Agustus 2015.

[11] S. W. Mudjanarko, S. Winardi, and A. D. Limantara, "Pemanfaatan internet of things (iot) sebagai solusi manejemen transportasi kendaraan sepeda motor," Pros. Semin. Nas. Apl. Teknol. Prasarana Wil. X, no. August, 2017, doi: 10.17605/OSF.IO/6UE4B.

[12] A. D. Triono et al., "Utilization of Pedestrian Movement on the Sidewalk as a Source of Electric Power for Lighting Using Piezoelectric Censors," in 2018 3rd IEEE International Conference on Intelligent Transportation Engineering, ICITE 2018, 2018, doi: 10.1109/ICITE.2018.8492624.

[13] A. D. Limantara, L. D. Krisnawati, S. Winardi, and S. W. Mudjanarko, "Solusi Pengawasan Kebijakan Mengatasi Kemacetan Jalan dan Parkir Kota Berbasis Internet Cerdas," Semin. Nas. Teknol. dan Rekayasa Inf., no. November, pp. 1-6, 2017.

[14] A. D. Limantara, S. Winarto, and S. W. Mudjanarko, "Sistem Pakar Pemilihan Model Perbaikan Perkerasan Lentur berdasarkan Indeks Kondisi Perkerasan (Pci)," Semin. Nas. dan Teknol. Fak. Tek. Universtas Muhammadiyah Surakarta, no. November, pp. 1-2, 2017, [Online]. Available: https://jurnal.umj.ac.id/index.php/semnastek/article/view/1807.

[15] A. D. Limantara, Y. C. S. Purnomo, and S. W. Mudjanarko, "Pemodelan Sistem Pelacakan LOT Parkir Kosong Berbasis Sensor Ultrasonic Dan Internet Of Things ( IOT ) Pada Lahan Parkir Diluar Jalan," Semin. Nas. Sains dan Teknol., vol. 1, no. 2, pp. 1-10, 2017. 
[16] A. D. Limantara et al., "Optimization of standard mix design of porous paving coconut fiber and shell for the parking area," in AIP Conference Proceedings, 2018, vol. 2020, doi: 10.1063/1.5062655.

[17] A. D. Limantara, A. Widodo, S. Winarto, L. D. Krisnawati, and S. W. Mudjanarko, "Optimizing the use of natural gravel Brantas river as normal concrete mixed with quality fc $=19.3 \mathrm{Mpa}$," in IOP Conference Series: Earth and Environmental Science, 2018, vol. 140, no. 1, doi: 10.1088/17551315/140/1/012104.

[18] S. Wiwoho Mudjanarko et al., "The Concrete Quality Testing for Trapezoidal Model of the Prefabricated Foundation," Int. J. Eng. Technol., vol. 7, no. January, pp. 311-315, 2018, doi: 10.14419/ijet.v7i3.25.17588.

[19] D. A. Yulmida, S. W. Mudjanarko, M. I. Setiawan, and A. D. Limantara, "Analisis Kinerja Parkir Sepanjang Jalan Walikota Mustajab," U KaRsT, vol. Volume1, no. nomor1, pp. 39-46, 2017, doi: http://dx.doi.org/10.30737/u\%20karst.v1i1.81.

[20] A. D. Limantara, E. Gardjito, A. Ridwan, E. Sustiyatik, P. Pudijohartomo, and H. L. Sudarmanto, "The Effect of Bioconc Against Compressive Strength of Paving Concrete Combining Natural Materials," vol. 7, no. x, pp. 89-91, 2018.

[21] A. D. Limantara and S. W. Mudjanarko, "Investigasi Forensik Kerusakan Perkerasan Lentur Jalan Raya," UKaRsT, vol. 1, no. 1, pp. 85-105, 2017.

[22] E. Gardjito, A. D. Limantara, B. Subiyanto, and S. W. Mudjanarko, "Role of Project Related Parties on Quality Control (Concrete Structure) and Achievement of Project Performance," U KaRsT, vol. 2, no. 1, pp. 81-100, 2018.

[23] A. D. Limantara, E. Gardjito, B. Subiyanto, and S. W. Mudjanarko, "Modeling Decision Support to Prioritize Pavement Maintenance Activities in Indonesia," UKaRsT, vol. 2, no. 1, pp. 41-60, 2018.

[24] S. W. Mudjanarko, A. D. Limantara, B. Subiyanto, and F. Nurzandah, "Optimization of Standard Mix Design of Porous Paving Coconut Fiber for Parking Area," UKaRsT, vol. 2, no. 1, pp. 61-80, 2018.

[25] D. A. Restuti, L. Rifani, A. D. Limantara, and B. Subiyanto, "APLIKASI WEB MIX DESAIN BETON BERDASARKAN METODE DOE (SNI 03-28472002)," U KaRsT, vol. 1, no. 2, pp. 36-50, 2017.

[26] E. Gardjito, A. D. Limantara, B. Subiyanto, and S. W. Mudjanarko, "PENGENDALIAN MUTU BETON DENGAN METODE CONTROL CHART (SPC) DAN PROCESS CAPABILITY (SIX-SIGMA) PADA PEKERJAAN KONSTRUKSI," U KaRsT, vol. 1, no. 2, pp. 80-105, 2017. 
[27] N. Damastuti, R. D. Nasihien, A. D. Limantara, and B. Subiyanto, "COMPUTATIONAL FLUID DYNAMICS (CFD) UNTUK SIMULASI ALIRAN FLUIDA PADA BANGUNAN MASJID UNIVERSITAS NAROTAMA," U KaRsT, vol. 1, no. 2, 2017.

[28] A. Situmorang, A. D. Limantara, B. Subiyanto, and S. W. Mudjanarko, "PENINGKATAN DAYA DUKUNG TANAH DASAR LEMPUNG EKSPANSIF DENGAN STABILISASI KAPUR DAN GARAM," $U$ KaRsT, vol. 1, no. 2, pp. 68-79, 2017.

[29] W. Arganata, A. D. Limantara, and Y. Cahyo, "Analisis Perencanaan Overlay Pada Ruas Jalan Craken-Ngulungkulon Nambak-Ngulungkulon Dengan Bahan Acl Menggunakan Metode Bina," J. Manaj. Teknol. Tek. Sipil, vol. 2, no. 1, pp. 121-131, 2017. 